\title{
Inhibition of invasion and induction of apoptosis by selenium in human malignant brain tumour cells in vitro
}

\author{
HARCHARAN K. ROOPRAI ${ }^{1}$, IOANNIS KYRIAZIS ${ }^{2}$, ROBERT K. NUTTALL ${ }^{3}$, \\ DYLAN R. EDWARDS ${ }^{3}$, DANIEL ZICHA ${ }^{4}$, DEBORAH AUBYN $^{4}$, \\ DEREK DAVIES $^{5}$, RICHARD GULLAN ${ }^{6}$ and GEOFFREY J. PILKINGTON ${ }^{2}$
}

\begin{abstract}
${ }^{1}$ Biomedical Sciences, School of Health and Social Sciences, Middlesex University, Queensway, Enfield, Middlesex, EN3 4SA; ${ }^{2}$ Institute of Biomedical and Biomolecular Sciences, School of Pharmacy and Biomedical Sciences, University of Portsmouth, St. Michael's Building, White Swan Road, Portsmouth, PO1 2DT; ${ }^{3}$ School of Biological Sciences, University of East Anglia, Norwich, NR4 7TJ; ${ }^{4}$ Light Microscopy Laboratory and ${ }^{5}$ FACS Laboratory, London Research Institute, Cancer Research UK, London, WC2A 3PX; ${ }^{6}$ Department of Neurosurgery, King's College Hospital, London, SE5 9RS, UK
\end{abstract}

Received December 19, 2006; Accepted February 15, 2007

\begin{abstract}
Selenium is considered to be one of the most promising micronutrients for cancer prevention and therapy, based on evidence from epidemiological studies, laboratorybased research and clinical trial intervention. There are ample reports of selenium methionine and sodium selenite's ability to induce apoptosis in various cancers in vitro. There are a few reports in the literature on the effects of selenium on established glioma cell lines but none on biopsy-derived short-term brain tumour cultures. In this in vitro study the effects of a range of concentrations $(2-10 \mu \mathrm{g} / \mathrm{ml})$ of sodium selenite were investigated in one low-passage culture of biopsyderived glioma cells (IPSB-18, an anaplastic astrocytoma, P 18-22) and a normal human brain cell culture (CC2565, P11). Results from 2 viability assays, 3[4,5-dimethylthiazole-2-yl]2,5-diphenyltetrazolium bromide (MTT) and sulphorodamine B (SRB) consistently showed that the $\mathrm{IC}_{50}$ for selenium in the astrocytoma was approximately $5 \mu \mathrm{g} / \mathrm{ml}$ whilst the normal brain cells were unaffected by selenium in the range of concentrations studied. Time-lapse video microscopy revealed that, while at $4 \mu \mathrm{g} / \mathrm{ml}$ selenium, the time taken to achieve $100 \%$ cell death was $17 \mathrm{~h}$, with increasing concentrations of selenium from 6 to $8 \mu \mathrm{g} / \mathrm{ml}$ and finally at $10 \mu \mathrm{g} / \mathrm{ml}$ the IPSB-18 cells rounded up and died much more quickly. The time taken to achieve $100 \%$ cell death was $7 \mathrm{~h}, 7 \mathrm{~h}$ and $6 \mathrm{~h}$, respectively, suggesting that the effect was similar at higher concentrations. Flow cytometry indicated that cell death was by apoptosis. RT-PCR results showed downregulation of the gene expression
\end{abstract}

Correspondence to: Dr Harcharan K. Rooprai, Biomedical Sciences, School of Health and Social Sciences, Middlesex University, Queensway, Enfield, Middlesex, EN3 4SA, UK

E-mail: b.rooprai@mdx.ac.uk

Key words: selenium, anaplastic astrocytoma, apoptosis, brain tumours, matrix metalloproteases, therapeutic, invasion of 6 matrix metalloproteases $(M M P 2,9,14,15,16,24)$, their inhibitors, TIMPs and epidermal growth factor receptor, in IPSB-18 cells treated with 2,4 and $8 \mu \mathrm{g} / \mathrm{ml}$ of selenium. Collectively, the data in this study suggests that selenium, not only induces tumour cell-specific apoptosis but also has antiinvasive potential.

\section{Introduction}

Glioma is the most common type of primary malignant brain tumour and occurs at an incidence of around 10 per 100,000 capita. Malignant gliomas, grade III or anaplastic astrocytomas and grade IV or glioblastoma multiforme, are relatively rare and account for $2 \%$ of all cancers in adults (1). The median survival for anaplastic astrocytoma is 2 years whereas that for glioblastoma multiforme is 1 year. Current conventional therapies include surgery followed by radiotherapy. Chemotherapy is usually offered to patients at recurrence to provide adjuvant and palliative support (2-4). Surgery is not curative as local recurrence occurs due to the ability of these tumours to infiltratively invade the normal brain whereas radiotherapy can prolong survival. The prognosis for malignant gliomas has not improved significantly over the past three decades. However, recently, important advances in chemotherapy of recurrent gliomas have been the use of temozolomide, an oral alkylating agent (5) and carmustine (Gliadel wafers) (6). Nevertheless, these tumours remain incurable. Hence there is a strong need for new adjuvant therapies in the management of malignant gliomas. One such strategy, proposed by our group is the 'Nutraceutical Approach' which uses a combination of naturally occurring micronutrients (including selenium) which may act synergistically or additionally (7).

Selenium (Se) is a naturally occurring non-metallic trace element which has a bimodal effect; its beneficial effects occur in a limited range of daily intake, below which it cannot perform its essential function and above which its effects are toxic. Selenium is an integral part of several antioxidants, such as glutathione peroxidase, and has a role in functioning of the immune system (8). Selenium is found in foods such 
as brazil nuts, garlic, whole grain, mushrooms and eggs. Yet, it is not feasible to increase its daily intake to therapeutic levels by eating these foods alone because they have a very low selenium content (9). The amount of selenium in food is attributed to the selenium content in the soil, which can vary in different parts of the world (10). Selenium is present in plants in both inorganic (e.g. selenite and selenate) and organic (e.g. selenocysteine and selenomethionine, SeMet) forms (11). The organic forms are preferred for therapeutic intervention as they are more bioavailable than the inorganic ones.

Epidemiological studies have indicated that low selenium concentrations of Se are associated with increased risk of several types of cancer $(12,13)$. There is also an early report suggesting that there are lower cerebrospinal fluid levels of selenium in patients with malignant brain tumours compared to those with benign tumours (14). Selenium is reported to be widely distributed throughout the body but is particularly well maintained in the brain, even after its prolonged dietary deficiency (15). Indeed, it has been shown to accumulate in brain tumours $(16,17)$.

The protective role of selenium in cancer as a major clinical development was clearly demonstrated by the finding of Clark et al (18). They showed that taking $200 \mu \mathrm{g} /$ day of the most common form of selenium (selenium-enriched yeast) as a human dietary supplement, decreased cancer incidence and mortality rate by nearly $50 \%$. The form of selenium in this study was selenomethionine. However, it has been postulated very recently that there is a rationale for treating cancer with sodium selenite because of its relatively low toxicity (19). The doses of selenium used in cancer therapy have, nevertheless, been limited by concerns about its toxicity. A recent report, on 24 men with biopsy-proven prostate cancer who were given either 1600 or $3200 \mu \mathrm{g} /$ day of selenized yeast as part of a controlled clinical trial, suggested that there were no obvious selenium-related serious toxicities at these doses (20).

A few studies have reported that selenium induces apoptosis in established brain tumour cell lines in vitro (21-23) but there are no reports yet on low passage/short-term cultures of human glioma-derived cells. The aim of this study was to investigate the effects of sodium selenite on mediators of invasion (matrix metalloproteases, MMPs, and their inhibitors, tissue inhibitors of metalloproteinases, or TIMPs), expression of epidermal growth factor receptor (EGFR) and induction of apoptosis in an anaplastic astrocytoma cell culture (IPSB-18) and normal human astrocytes using a variety of techniques.

\section{Materials and methods}

Selenium. Inorganic selenium, sodium selenite $\left(\mathrm{Na}_{2} \mathrm{SeO}_{3}\right)$, was used instead of selenomethionine and solubilized in distilled water for use in this study. Since $172.9 \mathrm{~g}$ of sodium selenite (Sigma) contains $78.96 \mathrm{~g}$ of selenium, all calculations for preparing a range of concentrations were based on this, i.e. $2.19 \mathrm{~g}$ of the former is equivalent to $1 \mathrm{~g}$ of the latter.

Cell cultures. Surgical specimens from a patient with a grade III astrocytoma were obtained from the Neurosurgical staff at King's College Hospital, London. Biopsy material was used to establish a short-term cell culture (IPSB-18) which is now well characterised (24). The tumour was diagnosed, according to the World Health Organisation criteria (25), by a neuropathologist. Normal astrocytes (CC2565) at passage 11, from an 18-year-old male, purchased from Cambrex Biosciences, were used as a non-neoplastic control.

Cells were cultured as monolayers in small plastic culture flasks (Marathon) at $37^{\circ} \mathrm{C}, 5 \% \mathrm{CO}_{2}$ in a standard humidified incubator. Cells were maintained in Dulbecco's modified Eagle's medium (DMEM) supplemented with antibiotics/ antimycotic at the final concentration of $100 \mathrm{IU}$ penicillin, $100 \mu \mathrm{g}$ amphotericin per $\mathrm{ml}$ and $10 \%$ fetal calf serum (Sigma).

Cell viability assays. Two chemosensitivity assays were initially performed to determine the $\mathrm{IC}_{50}$ for selenium in 2 cell lines (IPSB-18 and CC2565) using MTT (3[4,5-dimethylthiazole-2-yl]-2,5-diphenyltetrazolium bromide) and SRB (sulphorodamine B).

The MTT assay (26) is based on the reduction of the tetrazolium salt MTT (Sigma) to formazan by the enzyme succinate dehydrogenase in viable mitochondria in the cells in the presence of clear DMEM (Invitrogen). The blue formazan product is then dissolved and quantified colourimetrically as an indicator of cell survival and proliferation (27).

Briefly, the $\mathrm{IC}_{50}$ value for selenium was determined by plating cells into 60 wells of a 96-well plate (Marathon) at a density of 10,000 cells per well in $200 \mu 1$ clear medium (Sigma) with no foetal calf serum. Cells were left overnight to adhere, after which the medium was replaced with fresh medium containing a range of concentrations of selenium $(3-10 \mu \mathrm{g} / \mathrm{ml})$ and incubated at $37^{\circ} \mathrm{C}$ for $8 \mathrm{~h}$. Six wells were used for each concentration and repeated three times. The negative and positive controls were clear medium and $0.1 \mathrm{M}$ sodium hydroxide solution $(\mathrm{NaOH})$, respectively. Cells were then incubated in MTT $(1 \mathrm{mg} / \mathrm{ml})$ for $1 \mathrm{~h}$. The formazan product was quantified spectroflurometrically by measuring absorbance at $570 \mathrm{~nm}$ on a Dynatech MR 700 microplate reader.

A second viability assay (28) was used for comparison purposes. SRB is a water soluble dye, which binds to the basic amino-acids of the cellular proteins. Thus, colorimetric measurement of the bound dye provides an estimate of the total protein mass that is related to the cell number. The cells were prepared and treated in the same way as for the MTT assay. After 8-h incubation with sodium selenite, viable cells were fixed to the bottom of each well with cold $50 \%$ trichloroacetic acid (TCA) at a final concentration of $10 \%$ and incubated for $1 \mathrm{~h}$ at $40^{\circ} \mathrm{C}$. The supernatant was aspirated and the plates were washed with distilled water. SRB solution was prepared $[0.4 \%(\mathrm{w} / \mathrm{v})$ in $1 \%$ acetic acid]. Then $200 \mu \mathrm{l}$ of SRB was added to each well and left for $30 \mathrm{~min}$ at room temperature. Unbound SRB was removed by washing with $1 \%$ glacial acetic acid followed by air drying. Bound SRB was solubilized by adding $200 \mu 1$ of Tris-buffer (10 mM, pH 10.5) to each well. The plates were then read spectrophotometrically on a Dynatech MR 700 microplate reader, at a wavelength of $570 \mathrm{~nm}$.

Statistical analysis. The absorbance values were analysed using Microsoft Excel 2000. For each parameter, the average of 6 wells was taken. Cells treated with medium were referred to as control (100\% viable) and the rest of the samples were expressed as percentage decreased viability compared with the control. The $\mathrm{IC}_{50}$ was estimated from the dose-response 
curve. Statistical significance of differences between samples treated with selenium and controls was determined by Student's t-test. P-values less than 0.05 were considered to be significant.

Time-lapse video microscopy (TLVM). IPSB-18 cells were plated in small petri dishes at a density of 30,000 and left overnight at $37^{\circ} \mathrm{C}$ to adhere. They were then washed and treated with 4 different concentrations of selenium: $4 \mu \mathrm{g} / \mathrm{ml}$, $6 \mu \mathrm{g} / \mathrm{ml}, 8 \mu \mathrm{g} / \mathrm{ml}$ and $10 \mu \mathrm{g} / \mathrm{ml}$. Untreated cells were used as controls. Filming was initiated $10 \mathrm{~min}$ after placing the petri dishes under the microscope. A selected area of the dish (with a few cells) was recorded over a period of $48 \mathrm{~h}$ at a 5-min lapse interval using 10X NA 0.25 objective. Four time-lapse video Olympus microscopes with digital recording were used for every session and the images were acquired using Kinetic Imaging (Merseyside, UK) AQM software.

Apoptosis determination by flow cytometry. Flow cytometry was also performed to confirm induction of apoptosis of IPSB-18 cells by selenium in TLVM. At confluence, cells were treated with various sodium selenite concentrations (effective selenium concentration range was $2-10 \mu \mathrm{g} / \mathrm{ml}$ ) for $24 \mathrm{~h}$. Then the cells were harvested and fixed with $70 \%$ ethanol and kept at $4^{\circ} \mathrm{C}$ for at least $30 \mathrm{~min}$ before further processing. Cells were washed twice in phosphate-citrate buffer (29), treated with $100 \mu \mathrm{g} / \mathrm{ml}$ RNase (Sigma) and stained with propidium iodide (PI; $50 \mu \mathrm{g} / \mathrm{ml}$, Sigma). Samples were analysed on a FACSCalibur (Becton-Dickinson, San Jose, CA) and at least 10,000 events were collected.

RNA extraction. Cells treated with various concentrations of selenium were harvested using Cell Dissociation Solution (Sigma) before adding $2 \mathrm{ml}$ of RNAzol reagent (Biogenesis, UK) to the pellet. RNA was solubilized by passing the lysate through a pipette several times. The next steps were carried out at $4^{\circ} \mathrm{C}$, including the centrifugations. Chloroform $(0.2 \mathrm{ml})$ was added, then it was vortexed for $15 \mathrm{sec}$ and centrifuged at $4,000 \mathrm{rpm}$ for $30 \mathrm{~min}$. Then, $800 \mu \mathrm{l}$ was taken from the upper phase and an equal volume of isopropanol was added to it. After mixing, the sample was incubated for $15 \mathrm{~min}$ and centrifuged at 4,000 rpm for $30 \mathrm{~min}$ followed by the addition of $70 \%$ ethanol $(2 \mathrm{ml})$ to the pellet. The sample was centrifuged (twice) for $15 \mathrm{~min}$. The pellet was resuspended in $100 \mu \mathrm{l}$ of double autoclaved water and incubated in a waterbath at $60^{\circ} \mathrm{C}$ for $15 \mathrm{~min}$ to dissolve RNA. Finally, the RNA (100 $\left.\mu \mathrm{l}\right)$ was diluted in $300 \mu 1$ of double distilled water. RNA concentration was then determined by measuring the optical density at $260 \mathrm{~nm}$ as follows: The sample $(3 \mu \mathrm{l})$ was diluted (x100) in double autoclaved water and analysed spectrophotometrically in triplicate. A control was also included using only double autoclaved distilled water. The RNA concentration was calculated as follows: mean value x100 (dilution factor) x40 $\mu \mathrm{g} / \mathrm{ml}$ (conversion factor for RNA).

Reverse transcription and quantitative PCR (polymerase chain reaction). Total RNA $(1 \mu \mathrm{g})$ was reverse transcribed using $2 \mu \mathrm{g}$ random hexamers (Amersham) and 200 units of Superscript II reverse transcriptase (Invitrogen Life Technologies). Sequences for primers and probes are described elsewhere (30), while 18S rRNA (primers and probes from Applied
Selenium MTT Assay

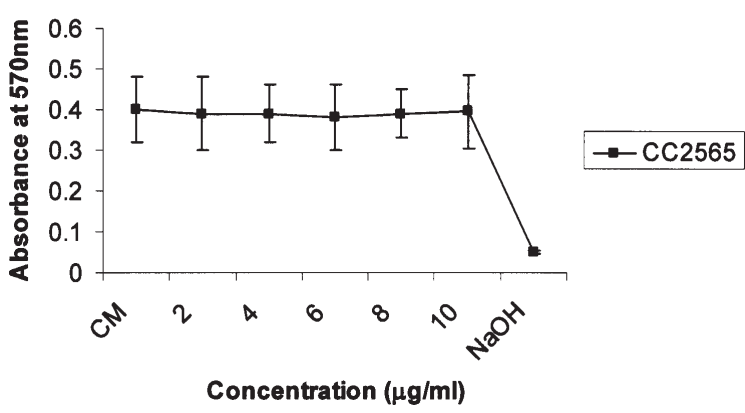

Figure. 1 Effect of treating normal human brain astrocytes (C2565) with a range of concentrations of sodium selenite. Cells were seeded at 10,000/well in a 96-well plate and treated for $8 \mathrm{~h}$. Cell viability was measured by MTT assay. Each point represents the mean \pm SEM of triplicate data.

Biosystems) was used as an endogenous control to account for differences in the extraction and reverse transcription of total RNA. PCR (polymerase chain reaction) was performed using the ABI PRISM 7700 Sequence Detection System (Applied Biosystems), using the manufacturer's protocol. Each reaction was performed in $25 \mu 1$ and contained the equivalent of $5 \mathrm{ng}$ of reverse transcribed RNA (1 ng RNA for the $18 \mathrm{~S}$ analyses), 50\% TaqMan 2X PCR Master Mix (Applied Biosystems), $100 \mathrm{nM}$ each of the forward and reverse primer, and $200 \mathrm{nM}$ of probe. Conditions for the PCR reaction were $2 \mathrm{~min}$ at $50^{\circ} \mathrm{C}, 10 \mathrm{~min}$ at $95^{\circ} \mathrm{C}$ and then 40 cycles, each consisting of $15 \mathrm{sec}$ at $95^{\circ} \mathrm{C}$, and $1 \mathrm{~min}$ at $60^{\circ} \mathrm{C}$. To determine the relative RNA levels within the samples, standard curves for the PCR reaction were prepared by using the cDNA from one sample and making 2-fold serial dilutions covering the range equivalent to $20 \mathrm{ng}$ to $0.625 \mathrm{ng}$ of RNA (for $18 \mathrm{~S}$ analyses the range was from 4 to $0.125 \mathrm{ng}$ ). These dilutions were subject to real-time PCR as described above. Relative standard curves for cycle threshold $\left(\mathrm{C}_{\mathrm{T}}\right)$ versus input RNA were prepared, and relative levels of starting RNA in each sample were determined. The results for each target mRNA were normalized to those from 18S ribosomal RNA from the same sample. RNA from the IPSB-18 cell line was extracted using a PCR method to look at gene expression of MMPs and their inhibitors, TIMPs as well as EGFR in the samples with or without the addition of selenium at 2 concentrations (4 and $8 \mu \mathrm{g} / \mathrm{ml}$ ).

\section{Results}

MTT and SRB cell viability assays. We used 2 different viability assays to determine the $\mathrm{IC}_{50}$ value for selenium selenite in an anaplastic astrocytoma cell line (IPSB-18) at passage 18 and normal astrocytes at passage 11 . The normal astrocytes were unaffected by selenium at all the concentrations studied (Fig. 1) whereas the $\mathrm{IC}_{50}$ was estimated to be approximately $5 \mu \mathrm{g} / \mathrm{ml}$ for the IPSB-18 cell line. There was a decrease in cell viability in a dose-response manner with the maximum effect seen with the highest concentration used $(10 \mu \mathrm{g} / \mathrm{ml})$. The results from both MTT and SRB assays were in agreement as indicated in Fig. 2A and B. As expected, susceptibility of the cultures to effects of selenium depended on the cell types used. Thus, it was not surprising to see that the normal astrocytic cultures 
A

Selenium MTT Assay

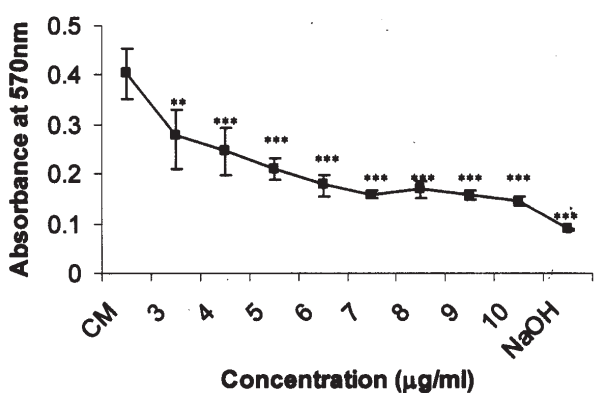

- - IPSB-18 p18

B

Solenium SRB Assay

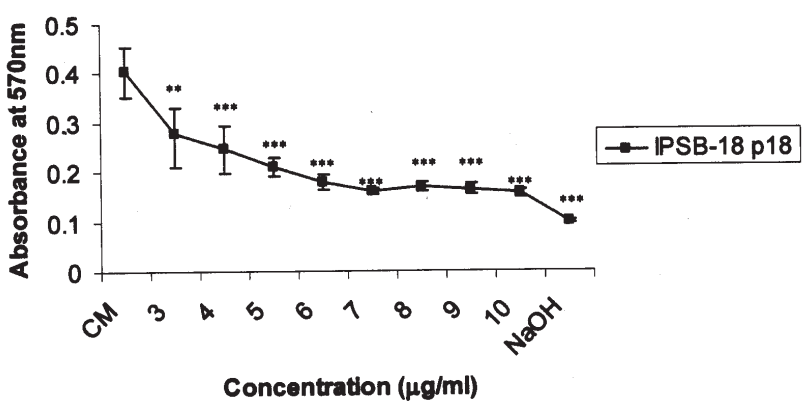

Figure 2. Effect of treating an anaplastic astrocytoma cell line (IPSB-18) with a range of concentrations of sodium selenite. Cells were seeded at 10,000/well in a 96-well plate and treated for $8 \mathrm{~h}$. Cell viability was measured. Each point represents the mean \pm SEM of triplicate data. ${ }^{* * *} \mathrm{~A}$ significant effect $(\mathrm{p}<0.05)$. The $\mathrm{IC}_{50}$ was found to be consistent $(5 \mu \mathrm{g} / \mathrm{ml})$ when using either the MTT assay (A) or the SRB assay (B).

Table I. Time taken to achieve $100 \%$ cell death in IPSB-18 cells (P18), as assessed by TLVM, when treated with 4 different concentrations of selenium.

\begin{tabular}{lc}
\hline Treatment & $\begin{array}{c}\text { No. of hours taken } \\
\text { to achieve } 100 \% \text { cell death }\end{array}$ \\
\hline Untreated & No apparent cell death \\
$4 \mu \mathrm{g} / \mathrm{ml}$ selenium & 17 \\
$6 \mu \mathrm{g} / \mathrm{ml}$ selenium & 7 \\
$8 \mu \mathrm{g} / \mathrm{ml}$ selenium & 7 \\
$10 \mu \mathrm{g} / \mathrm{ml}$ selenium & 6 \\
\hline
\end{tabular}

were unaffected in the range of concentrations of selenium used in this study (Fig. 1). Subsequent studies were performed on IPSB-18 cell cultures only.

Time-lapse video microscopy. TLVM was carried out to evaluate whether selenium affected the proliferation of the malignant brain tumour cells as well as induction of apoptosis at 4 different concentrations compared with untreated cells. The results indicate that the time taken for cell death to occur decreases at higher concentrations of selenium used in the study. The videos showed that treatment with increasing concentrations of selenium made the cells round up more
A

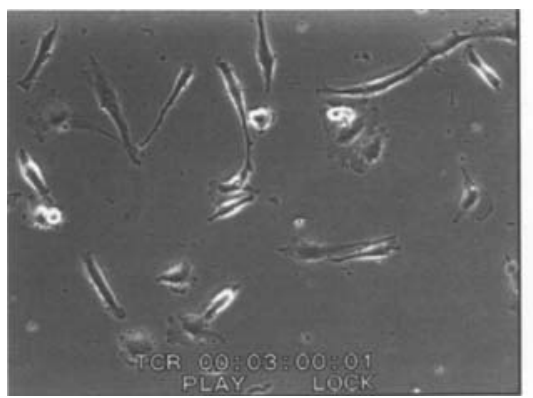

B

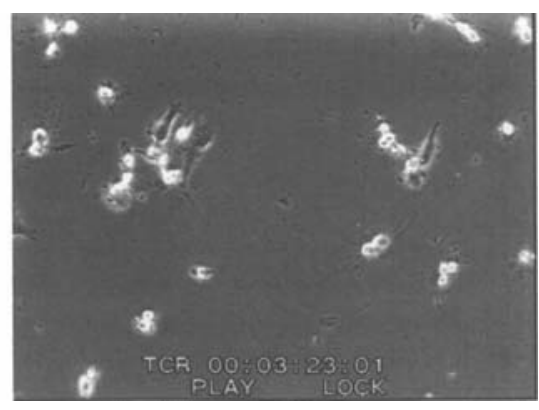

Figure 3. Time-lapse video miscroscopy data to illustrate an untreated monolayer of IPSB-18 cells in a selected area of a small petri dish. The cells were motile, proliferated and showed no obvious signs of cell death (A) after $48 \mathrm{~h}$ of filming. When the cells were treated with $4 \mu \mathrm{g} / \mathrm{ml}$ of sodium selenite, the cells become less motile, some cells rounded up (white cells in B) and died, suggesting that selenium induced apoptosis at this concentration.

A

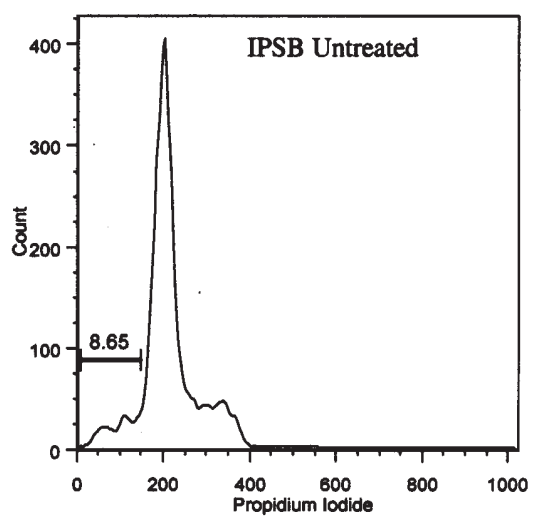

B

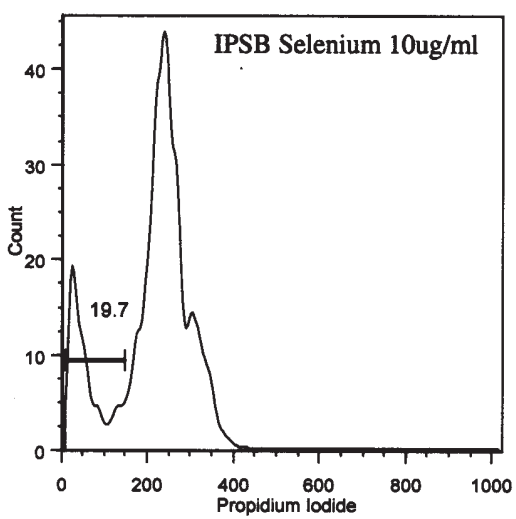

Figure 4. Flow cytometry results showed an increase in the sub-G1 hypodiploid population indicated by an increase in the percentage of cells in that region (B, treatment with selenium) compared with the untreated IPSB-18 cells (A). 
Table II. Sequences of PCR primers and sequence-specific probes for MMP2, 9, 14, 15, 16, 17, 24, 25, TIMP1, TIMP2, TIMP3, TIMP4 and EGFR targets.

TaqMan primers and probes

\begin{tabular}{|c|c|c|}
\hline$M M P 2$ & $\begin{array}{l}\text { Forward primer: } \\
\text { Reverse primer: } \\
\text { Probe: }\end{array}$ & $\begin{array}{l}\text { 5'-TGGCGATGGATACCCCTTT-3' } \\
\text { 5'-TTCTCCCAAGGTCCATAGCTCAT-3' } \\
\text { 5'-FAM-CTCCTGGCTCATGCCTTCGCCC-TAMRA-3' }\end{array}$ \\
\hline$M M P 9$ & $\begin{array}{l}\text { Forward primer: } \\
\text { Reverse primer: } \\
\text { Probe: }\end{array}$ & $\begin{array}{l}\text { 5'-CCTGGGCAGATTCCAAACCT-3' } \\
\text { 5'-GCAAGTCTTCCGAGTAGTTTTGGAT -3' } \\
\text { 5'-FAM-CTCAAGTGGCACCACCACAACATCACC-TAMRA-3' }\end{array}$ \\
\hline MMP14 & $\begin{array}{l}\text { Forward primer: } \\
\text { Reverse primer: } \\
\text { Probe: }\end{array}$ & $\begin{array}{l}\text { 5'-AGGCCGACATCATGATCTTCTTT-3' } \\
\text { 5'-AAGTGGGTGTCTCCTCCAATGTT-3' } \\
\text { 5'-FAM-CCATGGCGACAGCACGCCCTT-TAMRA-3' }\end{array}$ \\
\hline MMP15 & $\begin{array}{l}\text { Forward primer: } \\
\text { Reverse primer: } \\
\text { Probe: }\end{array}$ & $\begin{array}{l}\text { 5'-ATGCGTTCCGCCCAGAT-3' } \\
\text { 5'-GCCGCTTCATCCACTCCTT-3' } \\
\text { 5'-FAM-TCCCAGTCACCGGTGTGCTCGAC-TAMRA-3' }\end{array}$ \\
\hline MMP16 & $\begin{array}{l}\text { Forward primer: } \\
\text { Reverse primer: } \\
\text { Probe: }\end{array}$ & $\begin{array}{l}\text { 5'-ATGATTTACAGGGCATCCAGAAA-3' } \\
\text { 5'-TGGAGGCCGAGGAGGTTT-3' } \\
\text { 5'-FAM-CAAGATT CCTCCACCTACAAGACCTCTACCGAC-TAMRA-3' }\end{array}$ \\
\hline MMP17 & $\begin{array}{l}\text { Forward primer: } \\
\text { Reverse primer: } \\
\text { Probe: }\end{array}$ & $\begin{array}{l}\text { 5'-GCGGGTATCCTTCCTCTACGTT-3' } \\
\text { 5'-CAGCGACCACAAGATCGTCTT-3' } \\
\text { 5'-FAM-TGTCCTTGAACACCCAGTACCTGTCTCCTTTAA-TAMRA-3' }\end{array}$ \\
\hline MMP24 & $\begin{array}{l}\text { Forward primer: } \\
\text { Reverse primer: } \\
\text { Probe: }\end{array}$ & $\begin{array}{l}\text { 5'-CCAGTACATGGAGACGCACAA-3' } \\
\text { 5'-TGCGGACGGGGAGTGT-3' } \\
\text { 5'-FAM- CAGGGCATCCAGAAGATCTATGGACCC-TAMRA-3' }\end{array}$ \\
\hline MMP25 & $\begin{array}{l}\text { Forward primer: } \\
\text { Reverse primer: } \\
\text { Probe: }\end{array}$ & $\begin{array}{l}\text { 5'-GACGATGAGGAGACCTGGACTTT-3' } \\
\text { 5'-CCTGGTAGAAGGGCCTCATAATG-3' } \\
\text { 5'-FAM-CCGACCTGTTTGCCGTGGCTGTC-TAMRA-3' }\end{array}$ \\
\hline TIMP1 & $\begin{array}{l}\text { Forward primer: } \\
\text { Reverse primer: } \\
\text { Probe: }\end{array}$ & $\begin{array}{l}\text { 5'-GACGGCCTTCTGCAATTCC-3' } \\
\text { 5'-GTATAAGGTGGTCTGGTTGACTTCTG-3' } \\
\text { 5'-FAM-ACCTCGTCATCAGGGCCAAGTTCGT-TAMRA-3' }\end{array}$ \\
\hline TIMP2 & $\begin{array}{l}\text { Forward primer: } \\
\text { Reverse primer: } \\
\text { Probe: }\end{array}$ & $\begin{array}{l}\text { 5'-GAGCCTGAACCACAGGTACCA-3' } \\
\text { 5'-AGGAGATGTAGCACGGGATCA-3' } \\
\text { 5'-FAM-CTGCGAGTGCAAGATCACGCGC-TAMRA-3' }\end{array}$ \\
\hline TIMP3 & $\begin{array}{l}\text { Forward primer: } \\
\text { Reverse primer: } \\
\text { Probe: }\end{array}$ & $\begin{array}{l}\text { 5'-CCAGGACGCCTTCTGCAA-3' } \\
\text { 5'-CCCCTCCTTTACCAGCTTCTTC-3' } \\
\text { 5'-FAM-CGACATCGTGATCCGGGCCA-TAMRA-3' }\end{array}$ \\
\hline TIMP4 & $\begin{array}{l}\text { Forward primer: } \\
\text { Reverse primer: } \\
\text { Probe: }\end{array}$ & $\begin{array}{l}\text { 5'-CACCCTCAGCAGCACATCTG-3' } \\
\text { 5'-GGCCGGAACTACCTTCTCACT-3' } \\
\text { 5'-FAM-CACTCGGCACTTGTGATTCGGG-TAMRA-3' }\end{array}$ \\
\hline$E G F R$ & $\begin{array}{l}\text { Forward primer: } \\
\text { Reverse primer: } \\
\text { Probe: }\end{array}$ & $\begin{array}{l}\text { 5'-CGTTTGGGAGTTGATGACCTTT-3' } \\
\text { 5'-GGCTGAGGGAGGCGTTCT-3' } \\
\text { 5'-FAM-AGCCATATGACGGAATCCCTGCCAG-TAMRA-3' }\end{array}$ \\
\hline
\end{tabular}

Probes contain a FAM fluorescent reporter on the 5' end and TAMRA quencher on the $3^{\prime}$ end.

quickly. Whereas at $10 \mu \mathrm{g} / \mathrm{ml}$ selenium, $100 \%$ cell death was achieved in $6 \mathrm{~h}$, the same percentage of death was evident with $8 \mu \mathrm{g} / \mathrm{ml}$ in $7 \mathrm{~h}, 6 \mu \mathrm{g} / \mathrm{ml}$ in $7 \mathrm{~h}$, and $4 \mu \mathrm{g} / \mathrm{ml}$ in $17 \mathrm{~h}$ and there was no apparent cell death in untreated cells (Table I). Therefore, it appears that the net effect is the same because the cells are compromised following exposure to selenium, but the length of time for this effect to be apparent is dependent upon the concentrations used. Selected results are shown in Fig. 3A, which shows the cells at the beginning of filming, and in Fig. 3B, which shows a few cells rounded up indicating cell death. The nature of cell death i.e. necrosis or apoptosis, was confirmed by flow cytometry. 

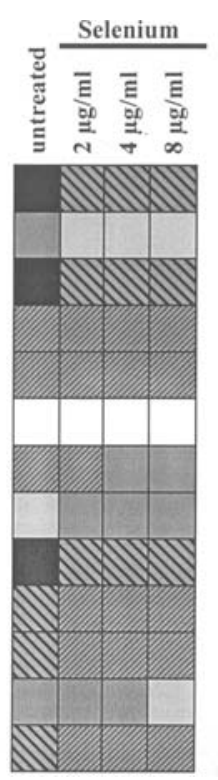

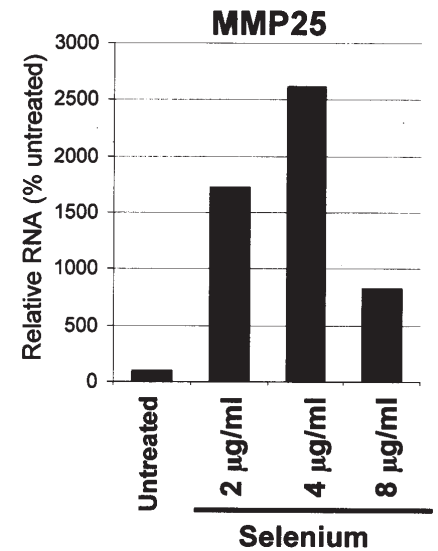

Figure 7. The expression of $M M P-25$ was elevated by selenium. Human biopsy-derived glioma cells were treated with selenium $(2-8 \mu \mathrm{g} / \mathrm{ml})$. The y-axis for each gene is relative mRNA levels normalized to $18 \mathrm{~S}$ rRNA levels, with the untreated sample set at $100 \%$.
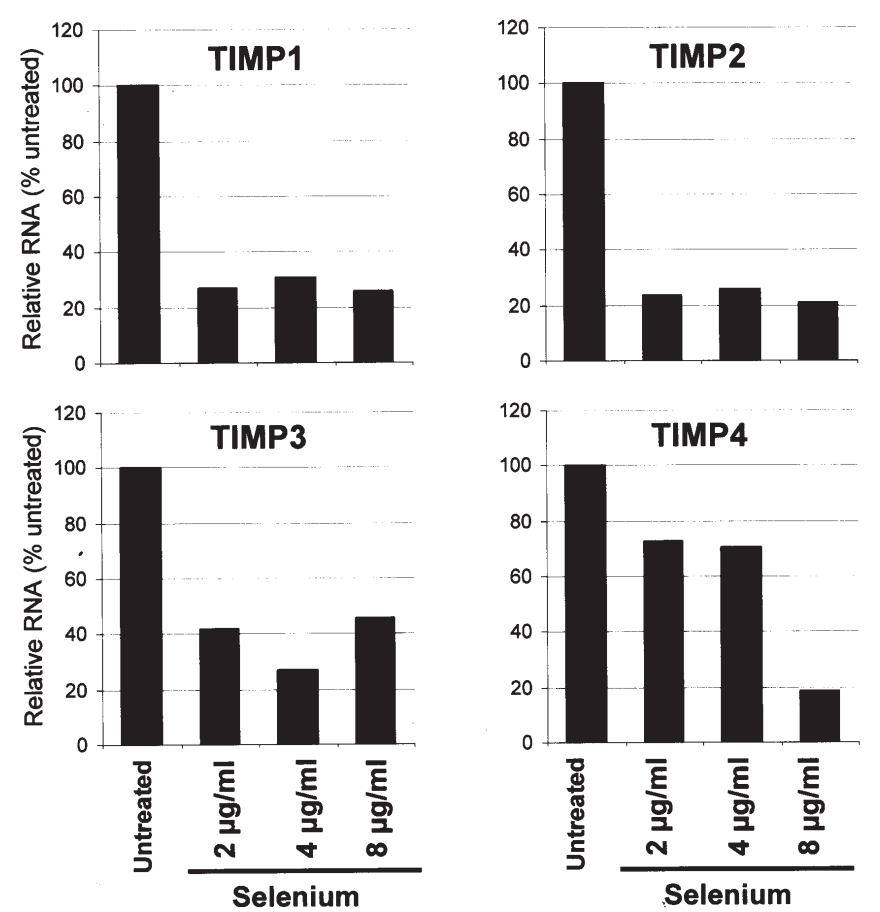

Figure 8 . The expression levels of the TIMPs were reduced by selenium. Human biopsy-derived glioma cells were treated with selenium $(2-8 \mu \mathrm{g} / \mathrm{ml})$. The $y$-axis for each gene is relative mRNA levels normalized to $18 \mathrm{~S}$ rRNA levels, with the untreated sample set at $100 \%$.

Flow cytometry. The cell death seen, using TLVM, with treatment of selenium at various concentrations was shown by flow cytometry to be apoptosis. This was indicated by an increase in the sub-G1 hypodiploid population when the IPSB-18 cell cultures were treated with $10 \mu \mathrm{g} / \mathrm{ml}$ selenium (Fig. 4).

Qualitative real-time $R T-P C R$. Gene expression profiles of 8 MMPs (the gelatinases: $M M P 2$, and $M M P 9$; and the membrane-type MMPs: MMP14, 15, 16, 17, 24 and 25), their inhibitors (TIMP1, 2, 3, and 4) and EGFR were studied using TaqMan (Table II, Figs. 5-9) when IPSB-18 cell cultures (P18) were either untreated or treated with $2 \mu \mathrm{g} / \mathrm{ml}, 4 \mu \mathrm{g} / \mathrm{ml}$ or $8 \mu \mathrm{g} / \mathrm{ml}$. Differential gene profiles were seen in the untreated
Figure 6. The expression levels of several MMPs were reduced by selenium. Human biopsy-derived glioma cells were treated with selenium $(2-8 \mu \mathrm{g} / \mathrm{ml})$. The $y$-axis for each gene is relative mRNA levels normalized to $18 \mathrm{~S}$ rRNA levels, with the untreated sample set at $100 \%$. 


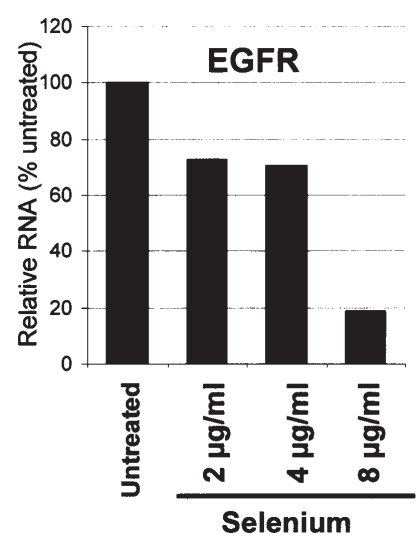

Figure 9. The expression of EGFR was reduced by selenium. Human biopsyderived glioma cells were treated with selenium $(2-8 \mu \mathrm{g} / \mathrm{ml})$. The $\mathrm{y}$-axis for each gene is relative mRNA levels normalized to $18 \mathrm{~S}$ rRNA levels, with the untreated sample set at $100 \%$.

glioma cells such that $M M P 17$ was not detected at all, there was low expression for MMP9. MMP25 and TIMP4 exhibited low expression, whereas the membrane type-MMPs, MMP15, $M M P 16$ and MMP24 showed moderate expression. Moreover, TIMP2, TIMP3 and EGFR were highly expressed with very high expression apparent for MMP2, MMP14 and TIMP1 (Fig. 5). Invariably, treatment with selenium (at 2, 4 or $8 \mu \mathrm{g} / \mathrm{ml}$ ) down-regulated the gene expression of MMPs, their inhibitors and EGFR (Figs. 5-9). Indeed, the effect of selenium in the chosen range of concentrations was not dose-related generally. An unexpected effect seen by selenium treatment was the elevation of MMP25 expression; clearly this is an important finding, since it shows that the reduced MMP levels on treatment are not just an experiment artefact. Collectively, these results suggest that selenium may also have an antiinvasive effect on glioma cells in vitro.

\section{Discussion}

Numerous epidemiological studies, preclinical investigations and clinical trials have supported the protective role of selenium in cancer (18,31-35). It is well documented that both inorganic (21-23) and organic forms (36) of selenium are cytotoxic to human cancer cells in vitro. The potential anti-cancer actions of selenium are known to include induction of apoptosis, inhibition of angiogenesis and vascular endothelial growth factor (VEGF) effects (8) but there has not been any evidence for selenium acting as an anti-invasive agent either.

Considerable evidence is documented for the effects of organic and inorganic forms of selenium, on induction of apoptosis in cancer cells generally. The TLVM data indicated that the cells became less motile with increasing concentrations of selenium. At higher concentrations used, the cells died quickly. Indeed, there is impaired cell proliferation, probably by enhanced programmed cell death in the selenium-treated cells. Subsequently, the flow cytometry data indicated the mode of death to be apoptosis. Previous workers (21-23) have suggested that selenium may induce apoptosis in glioma cells in vitro at similar $\mathrm{IC}_{50}$ values. Sundaram et al (23) evaluated nuclear chromatin condensation by electron microscopy as a means of determining induction of apoptosis in established glioma cell lines. Ultrastructurally, they found that the mitochondria in the glioma cells had electron dense inclusions as a result of selenium treatment. Perhaps, sodium seleniteinduced apoptosis is mediated by the mitochondrial pathway, in malignant brain tumour cells. Understanding apoptotic mechanisms at the molecular level is important for identifying points of intervention in a clinical setting and this could be investigated by measuring changes in mitochondria and activation of specific caspases.

However, established cell lines (T98G, U87MG, U373MG, A172 and C6), which are homogenous, have been studied by some of them previously, whereas we have studied a shortterm culture of a biopsy-derived glioma cell line which we have earlier shown to be very heterogeneous (24). The $\mathrm{IC}_{50}$ for sodium selenite for A172 and T98G cells was $10 \mu \mathrm{M}(21,22)$ and $(2-4 \mu \mathrm{g} / \mathrm{ml}=10-20 \mu \mathrm{M})$ for TG98G, U373MG, U87MG cells (23). The $\mathrm{IC}_{50}$ for our cell line, IPSB-18 at passage 18-22, was slightly higher $(5 \mu \mathrm{g} / \mathrm{ml})$. Moreover, our normal astrocyte cultures were unaffected within the range of concentrations of sodium selenite used in this study for the glioma cell line. It is likely that very high concentrations of sodium selenite would be toxic, unlike selenomethionine which has been reported by other workers (36) to have an $\mathrm{IC}_{50}$ of $1 \mathrm{mM}$ for fibroblasts, approximately 1000 times higher than the various human cancer cells they used (which ranged from 45-130 $\mu \mathrm{M}$ ).

The hallmarks of human malignant gliomas are their diffuse invasiveness and vascularity. Angiogenesis and tumour invasion are two important biological features associated with increased extracellular matrix (ECM) degradation in which MMPs and other proteases play a critical role. Of the 23 MMPs reported in humans, overexpression of some of them, particularly the membrane-type MMPs, has been previously reported in malignant gliomas $(30,37,38)$. Moreover, it has also been suggested that of the gelatinases (MMP-2 and -9), MMP-9 may be associated with angiogenesis $(39,40)$ whereas MMP-2 and MMP-14 may be involved in both angiogenesis and tumour invasion (39). It is well documented that in the mechanism involved for the activation of MMP-2, it forms a ternary complex with MMP-14 and TIMP-2 such that the N-terminal domain of TIMP-2 binds to and inhibits MMP-14, whereas the C-terminal domain of the same TIMP-2 molecule binds the hemopexin-like domain of MMP-2.

To the best of our knowledge, this is the first report providing evidence for selenium's ability to interfere with parameters of invasion (and possibly angiogenesis) in a glioma cell line, since it downregulates gene expression of 6 MMPs (2 gelatinases; MMP2 and MMP9, and 4 membranetype MMPs; MMP14, 15, 16 and 24), their TIMPs and EGFR. Interestingly, selenium, at all the chosen concentrations, appears to have a superadditive effect on the ternary complex of MMP-2, -14 and TIMP-2, suggesting that it inhibits both invasion and angiogenesis. However, the elevation of $M M P 25$ gene expression, when the cells are treated with selenium, although difficult to explain, may be important, since it shows that the reduction of levels of the other MMPs is not just an experimental artefact. The IPSB-18 cells exhibited weak and low expression of this MMP, before and after treatment with selenium, respectively.

MMPs have other functions in addition to their role in invasion and angiogenesis and may mediate tumour growth. 
Similarly, TIMPs have a variety of functions beyond MMP inhibition (41), e.g. TIMP-3 is thought to promote apoptosis in some cancers. TIMP-1 was very strongly expressed in the present study but TIMP-2 showed low expression. Our findings for the expression of TIMP1 and TIMP4 were consistent with those of Groft et al (41). Thus it is likely that the downregulation of the expression by selenium may affect a variety of other functions.

Receptor tyrosine kinases that have been implicated in gliomas include the epidermal growth factor receptor (EGFR). Overexpression of this oncogene at $7 \mathrm{p} 12$ has been reported to occur in $90 \%$ of high-grade gliomas and $27-57 \%$ of lowgrade gliomas (42). The EGFR signalling pathway increases cellular proliferation and invasion and inhibits apoptosis. EGFR signals through three main pathways: the phosphoinositide-3 kinase (PI3K)/Akt pathway, the Ras mitogenic pathway and the Jak Stat pathway. Our results show a downregulation of EGFR gene expression at all concentrations of selenium, the effect being most dramatic at $8 \mu \mathrm{g} / \mathrm{ml}(80 \%$ inhibition) compared with 2 and $4 \mu \mathrm{g} / \mathrm{ml}$ (30\% inhibition).

It has been hypothesized that selenium status can be inversely related to the risk to some cancers and been supported by epidemiological studies. Also, a number of studies have shown that cancer patients are generally of slightly lower selenium status than healthy people, who have a median plasma selenium level of $128 \mathrm{ng} / \mathrm{ml}$.

One of the problems of working with biopsy-derived tumour cell cultures is the artificial environment created in this model which does not mimic the in vivo situation entirely. Established cell lines are very homogeneous in comparison. Although high levels of selenium used in this and other studies $(2-10 \mu \mathrm{g} / \mathrm{ml}=10-50 \mu \mathrm{M})$ indicated impaired cellular proliferation by enhanced apoptosis, it is not yet clear if this can be extrapolated to living systems in which selenium levels tend to be of a much lower magnitude (1-2 nM).

Earlier studies on rats have indicated that there were significantly higher concentrations of selenium accumulated in tumour tissue than normal brain tissue after exposure to sodium selenite (17). Selenium is known to be widely distributed throughout the body and is particularly well maintained in the brain, even after prolonged deficiency in dietary selenium. Moreover, changes in selenium concentrations in blood and brain have been reported in brain tumour patients (16).

There is ample evidence from clinical trails supporting the anticancer efficacy of selenium. In particular, a 10-year long trial by Clark et al (18) showed that the use of $200 \mu \mathrm{g}$ selenium/day as an oral supplement of selenium-enriched yeast did not affect the risk of recurrent skin cancers. However, compared to controls, selenium treatment was associated with lower incidences of cancer of the lung, colon-rectum and prostate. The combination of epidemiological data and experimental data from a variety of cancer studies and reports of clinical efficacy, make selenium one of the most promising micro-nutrients in cancer prevention and therapy generally.

Moreover, there is one earlier report of a small trial in 12 glioblastoma multiforme patients, who were given $150 \mu \mathrm{g}$ organic selenium and 60 IU Vitamin E for several weeks to 1 year, with no improvement in survival post-operatively (43). The patients were given selenium concurrently with immunotherapy with rabies vaccine after radiotherapy. Later, in another study, 32 patients with brain tumours, were given sodium selenite $(1,000 \mu \mathrm{g}$ by infusion in physiological saline) for 4-8 weeks (44). In $76 \%$ of the patients, there was a definite improvement of the general condition and a decrease in symptoms such as nausea, unsteady gait, etc.

Given that there are small therapeutic windows for drugs and often these drugs are given in a combination for various treatments, we have proposed to use a combination of micronutrients (including selenium) in brain tumour management (7) in anticipation of a synergistic/additive effect.

In conclusion, there may be 2 different modes of action of selenium in anaplastic astrocytoma cells in vitro: induction of apoptosis (which is a known effect of selenium in other cancers) and interference of parameters underlying tumour invasion and angiogenesis. The down-regulation of EGFR gene expression seen with selenium may also account for not only decreased cellular proliferation and invasion but also induction of apoptosis. This study suggests that selenium is a potentially valuable anti-glioma agent in the proposed clinical trial for the management of malignant brain tumours. Further experiments include studying the effects of selenium in 3 dimensional invasion assays and elucidation of mechanisms involved in selenium-induced apoptosis and interaction with EGFR signalling pathways.

\section{Acknowledgements}

This study was financially supported by Brain Tumour UK, Samantha Dickson Brain Tumour Trust, Rosetrees Trust and Have a Chance Inc. The authors are also grateful to Ms. Noor Azila and Ms. Satinder Kaur Flora for their valuable assistance.

\section{References}

1. McKinney PA: Brain tumours: incidence, survival and aetiology. J Neurol Neurosurg Psychiatry 75: 12-17, 2004.

2. Grant R: Overview: brain tumour diagnosis and management/ Royal College of Physicians guidelines. J Neurol Neurosurg Psychiatry 75: 18-23, 2004.

3. Grossman SA and Batara JF: Current management of glioblastoma multiforme. Semin Oncol 31: 635-644, 2004.

4. Rampling R, James A and Papanastassiou V: The present and future management of malignant brain tumours: Surgery, radiotherapy, chemotherapy. J Neurol Neurosurg Psychiatry 75: 24-30, 2004.

5. Stupp R, Mason WP, van den Bent MJ, et al: Radiotherapy plus concomitant and adjuvant temozolomide for glioblastoma. $\mathrm{N}$ Eng J Med 352: 987-996, 2005.

6. Westphal M, Hilt DC, Bortey E, et al: A phase 3 trial of local chemotherapy with biodegradable carmustine (BCNU) wafers (Gliadel wafers) in patients with primary malignant glioma. Neuro-Oncology 5: 79-88, 2003.

7. Rooprai HK, Christidou M and Pilkington GJ: The potential for strategies using micronutrients and heterocyclic drugs to treat invasive gliomas. Acta Neurochir 145: 683-690, 2003.

8. Boik J: Natural Compounds in Cancer Therapy. Silvine Farnell (ed). Oregon Medical Press, pp163-168, 2001.

9. Morris VC and Levander OA: Selenium content of foods. J Nutr 100: 1383-1388, 1970.

10. Tapiero H, Townsend DM and Tew KD: The antioxidant role of selenium and seleno-compounds. Biomed Pharmacother 57: 134-144, 2003.

11. Kadrabova J, Madaric A, Kovacikova Z and Ginter E: Selenium status, plasma zinc, copper and magnesium in vegetarians. Biol Trace Elem Res 50: 13-24, 1995.

12. Salonen JT, Salonen R, Lappeteläinen R, et al: Risk of cancer in relation to serum concentration of selenium and vitamins $\mathrm{A}$ and $\mathrm{E}$. Matched case-control analysis of prospective data. $\mathrm{Br}$ Med J 290: 417-420, 1985. 
13. Willet WS, Polk FB, Morris JS, et al: Prediagnostic serum selenium and risks of cancer. Lancet 2: 130-133, 1983.

14. El-Yazigi A, Al-Saleh IA and Al-Mefty O: Concentrations of $\mathrm{Ag}, \mathrm{Al}, \mathrm{Au}, \mathrm{Bi}, \mathrm{Cd}, \mathrm{Cu}, \mathrm{Pb}, \mathrm{Sb}$ and $\mathrm{Se}$ in cerebrospinal fluid of patients with central neoplasms. Clin Chem 30: 1358-1360, 1984.

15. Whanger PD: Selenium and the brain: a review. Nutr Neurosci 4: 81-97, 2001.

16. Chen J and Berry MJ: selenium and selenoproteins in the brain and brain diseases. J Neurochem 86: 1-12, 2003.

17. Zhang Z, Chinen Y, Zhu Z, Kimura M and Itokawa Y: Uptake and distribution of sodium selenite in rat brain tumor. Biol Trace Elem Res 48: 45-50, 1995.

18. Clark L, Combs GF, Turnbull BW, et al: Nutritional Prevention of Cancer Study Group. Effects of selenium supplementation for cancer prevention in patients with carcinoma of the skin. J Am Med Assoc 276: 1957-1963, 1996.

19. Lipinski B: Rationale for the treatment of cancer with sodium selenite. Med Hypotheses 64: 806-810, 2005.

20. Reid ME, Stratton MS, Lillico AJ, Fakih M, Natarajan R, Clark LC and Marshall JR: A report of high-dose selenium supplementation: response and toxicities. J Trace Elem Med Biol 18: 69-74, 2004.

21. Zhu Z, Kimura M, Itokawa Y, Nakatsu S, Oda Y and Kikuchi H: Effect of selenium on malignant tumour cells of brain. Biol Trace Elem Res 49: 1-7, 1995.

22. Zhu Z, Kimura M, Itokawa Y, Aoki T, Takahashi JA, Nakatsu S, Oda Y and Kikuchi H: Apoptosis induced by selenium in human glioma cell lines. Boil Trace Elem Res 54: 123-134, 1996.

23. Sundaram N, Pahwa A, Ard MD, Lin N, Perkins E and Bowles AP: Selenium causes growth inhibition and apoptosis in human brain tumour cell lines. J Neurooncol 46: 125-133, 2000.

24. Knott JCA, Edwards AJ, Gullan RW, Clarke TM and Pilkington GJ: A human glioma cell line retaining expression of GFAP and gangliosides, recognized by A2B5 and LB1 antibodies, after prolonged passage. Neuropath Appl Neurobiol 16: 489-500, 1990.

25. Kleihues P, Burger C and Scheithauer BW: Histological typing of tumours of the central nervous system. In: WHO Classification. Section Edition. Springer Verlag, Berlin, 1993.

26. Nikkhah G, Tonn JC, Hoffmann O, Kraemer HP, Darling JL, Schachenmayr W and Schonmayr R: The MTT assay for chemosensitivity testing of human tumors of the central nervous system. Part II: evaluation of patient and drug-specific variables. J Neurooncol 13: 13-24, 1992.

27. Marshall N, Goodwin CJ and Holts SJ: A critical assessment of the use of microculture tetrazolium assay to measure cell growth and function. Growth Regul 5: 69-84, 1995.

28. Skehan P, Storeng R, Scudiero D, et al: New colorimetric cytotoxicity assay for anticancer-drug screening. J Natl Cancer Inst 82: 1107-1112, 1990.
29. Gong J, Traganos FM and Darzynkiewicz Z: A selective procedure for DNA ectraction from apoptotic cells applicable for gel electrophoresis and flow cytometry. Anal Biochem 218: 314-319, 1994.

30. Nuttall RK, Pennington CJ, Taplin J, Wheal A, Yong VW, Forsyth PA and Edwards DR: Elevated membrane-type matrix metalloproteinases in gliomas revealed by profiling proteases and inhibitors in human cancer cells. Mol Cancer Res 1: 333-345, 2003.

31. Shamberger RJ and Frost DV: Possible protective effects of selenium against human cancer. Can Med Assoc J 100: 682, 1969.

32. El-Bayoumy K: The protective role of selenium on genetic damage and on cancer. Mutat Res 475: 123-139, 2001.

33. Abdulah R, Miyazaki K, Nakazawa M and Koyama H: Chemical forms of selenium for cancer prevention. J Trace Elem Med Biol 19: 141-150, 2005.

34. Nelson MA, Goulet AC, Jacobs ET and Lance P: Studies into the anticancer effects of selenomethionine against human colon cancer. Ann NY Acad Sci 1059: 26-32, 2005.

35. Rayman MP: Selenium in cancer prevention: a review of the evidence and mechanism of action. Proc Nutr Soc 64: 527-542, 2005.

36. Redman C, Scott JA, Baines AT, et al: Inhibitory effect of selenomethionine on the growth of three selected human tumor cell lines. Cancer Lett 125: 103-110, 1998.

37. VanMeter TE, Rooprai HK, Kibble MM, Fillmore HL, Broaddus WC and Pilkington GJ: The role of matrix metalloproteinase genes in glioma invasion: co-dependence and interactive proteolysis. J Neurooncol 53: 213-235, 2001.

38. Fillmore HL, VanMeter TE and Broaddus WC: Membranetype metalloproteinases (MT-MMPs): expression and function during glioma invasion. J Neurooncol 53: 187-202, 2001.

39. Forsyth PA, Wong H, Laing TD, et al: Gelatinase-A (MMP-2), gelatinase-B (MMP-9) and membrane type matrix metalloproteinase-1 (MT1-MMP) are involved in different aspects of the pathophysiology of malignant gliomas. Br J Cancer 79: 1828-1835, 1999.

40. Giles HV, Wagner S, Pietsch T, et al: Heterogenous regional expression patterns of matrix metalloproteinases in human malignant gliomas. Int J Dev Neurosci 17: 437-445, 1999.

41. Groft LL, Muzik H, Rewcastle NB, et al: Differential expression and localization of TIMP-1 and TIMP-4 in human gliomas. Br J Cancer 85: 55-63, 2001.

42. Shinojima N, Tada K, Shiraishi S, et al: Prognostic value of epidermal growth factor receptor in patients with glioblastoma multiforme. Cancer Res 20: 6962-6970, 2003.

43. Philipov PH and Tzatchev K: Selenium in the treatment of patients with brain gliomas. A pilot study. Zent Bl Neurochir 51: 145-146, 1990.

44. Pakdaman A: Symptomatic treatment of brain tumour patients with sodium selenite, oxygen, and other supportive measures. Biol Trace Elem Res 62: 1-6, 1998. 